\title{
Variety and N-Fertilizer Rate Influence the Growth, Yield and Yield Parameters of Baby Corn (Zea mays L.)
}

\author{
Md. Asaduzzaman ${ }^{1}$, Mrityunjoy Biswas ${ }^{2}$, Md. Nazrul Islam², Mohammad Mokhlesur Rahman ${ }^{1}$, Rafeza Begum ${ }^{3}$, \\ Md. Abdur Rahman Sarkar ${ }^{4}$, Md. Asaduzzaman ${ }^{5}$ \\ ${ }^{1}$ Wheat Research Centre, Regional Agricultural Research Station, Jamalpur, Bangladesh \\ ${ }^{2}$ Department of Agronomy and Haor Agriculture, Sylhet Agricultural University, Sylhet, Bangladesh \\ ${ }^{3}$ Regional Laboratory, Soil Resources Development Institute, Jamalpur, Bangladesh \\ ${ }^{4}$ Department of Agronomy, Bangladesh Agricultural University, Mymensingh, Bangladesh \\ ${ }^{5}$ Agronomy Division, Regional Agricultural Research Station, Jamalpur, Bangladesh \\ Correspondence: Md. Asaduzzaman, Agronomy Division, Regional Agricultural Research Station, \\ Jamalpur-2000, Bangladesh. Tel: 880-171-813-1545. E-mail: asadcbt@yahoo.com \\ Mrityunjoy Biswas, Department of Agronomy and Haor Agriculture, Sylhet Agricultural University, Sylhet, \\ Bangladesh. Tel: 880-171-124-0580. E-mail: biswasbari@yahoo.com
}

Received: November 26, 2013 Accepted: December 12, 2013 Online Published: February 15, 2014

doi:10.5539/jas.v6n3p118

URL: http://dx.doi.org/10.5539/jas.v6n3p118

\begin{abstract}
Four baby corn varieties viz. Hybrid baby corn-271, Shuvra, Khoibhutta and BARI sweet corn-1 were planted at five $\mathrm{N}$ fertilizer rates viz. $0,80,120,160$ and $200 \mathrm{~kg} \mathrm{~N} \mathrm{ha}^{-1}$ in the experiment to find out the suitable variety and $\mathrm{N}$ fertilizer rate for baby corn production. The experiment was carried out at the Regional Station under Bangladesh Agricultural Research Institute at Jamalpur, Bangladesh during rabi season of 2008-09. Hybrid baby corn-271 and Shuvra took about 85 days and Khoibhutta and BARI sweet corn-1 took about 71 days to first silking. The results revealed that the highest values was recorded in variety Shuvra with $200 \mathrm{~kg} \mathrm{~N} \mathrm{ha}^{-1}$ in most of the growth parameters which was statistically similar to $160 \mathrm{~kg} \mathrm{~N} \mathrm{ha}^{-1}$. Number of ear plant ${ }^{-1}$, length of ear, baby corn yield without husk and with husk varied significantly due to interaction of variety and N-rates. Baby corn yield without husk increased significantly with $160 \mathrm{~kg} \mathrm{~N} \mathrm{ha}^{-1}$ and beyond this rate yield increment was not significant in Hybrid baby corn-271 and Shuvra while N-rate increased baby corn yield without husk significantly not beyond $120 \mathrm{~kg} \mathrm{ha}^{-1}$ in Khoibhutta and BARI sweet corn-1. Number of cob plant ${ }^{-1}$ and length of cob were found the main yield parameters attributed to increased baby corn yield without husk.
\end{abstract}

Keywords: crop growth rate, ear yield, fodder yield, leaf area index, total dry matter

\section{Introduction}

Baby corn (Zea mays L.) the "Queen of Cereals" is grown almost throughout the world is an off shoot of maize which is grown for its young, fresh, finger like green ears, harvested at the time of silk emergence and before pollination and fertilization (Ramachandrappa, Nanjappa, \& Shivakumar, 2004). Baby corn has short growth duration offers an intensive rotation cultivation system which is an excellent solution for promoting economic and poverty alleviation in countries with high populations like Bangladesh, Vietnam, Thailand and the Philippines. The other advantage of growing baby corn is its remaining biomass after harvesting. These green products can be used as feed for animal and aquaculture raising (Bindhani, Barik, Garnayak, \& Mahapatra, 2007). Ears are ideal for baby corn if they are bite size, $5-10 \mathrm{~cm}$ long and $0.85-1.70 \mathrm{~cm}$ diameter at the base (Bar-zur \& Saadi, 1990). Expected yield is approximately 8500 pounds of unhusked baby corn ears acre ${ }^{-1}$, or 1140 pounds of husked baby corn ears acre ${ }^{-1}$. The baby corn has many uses. It is being used by Chinese as vegetables and this practice has spread to other Asian countries. Recently it is becoming popular very rapidly as vegetables, salad, pasta, soup, pakora, chutney, cutlets chat, dry vegetable, kofta curry, masala, manchurian, chilly, raita, pickle, candy, jam, murabba, burfi, halwa, kheer, laddo and other favorite dishes for different chinese hotels and restaurants in Bangladesh. Recently with the establishment of new dairy and beef fattening farms in our country, the demand of maize plants as a fodder are increasing day by day. Moreover stover, dry 
leaves and cob covering can be used as good fuel (Ahmed, 1994). Foreign exchange can be earned by exporting baby corn and its products (Das et al., 2008).

In Bangladesh, it is not commercially grown yet in different locations. At present, baby corn is growing some areas of Chittagong hill tracts. The soil and climate of our country is suitable for baby corn production. It can be grown all the year round (Salahuddin \& Ivy, 2003). It has short growth duration of about 70-80 days, thus the farmer can grow baby corn three or four times a year and thus farmers can earn money in the shortest possible time by cultivating baby corn even it can be fitted for any cropping pattern. Although the production and marketing started since 1992-93 in our country with the co-operation of IFDC but its uses, area and marketing facility have not yet been increased considerably. Eventually to meet the demand of baby corn it is imported from foreign countries like Thailand, Taiwan etc. and costing about Tk 10 (ten) crores per year (BARI, 2004). The yield of baby corn of our country is $0.99-1.1 \mathrm{t} \mathrm{ha}^{-1}$ (BARI, 2008). But its potentiality is $5 \mathrm{t} \mathrm{ha}^{-1}$ (BARI, 2004). Nevertheless it is not cultivated all over the country due to the lack of production technology knowledge. Growth of baby corn are affected by cultural management practices especially fertilizer application. The different levels of nutrition on corn plants greatly affected. Maximum and minimum nitrogen content differed in plants and also in different parts of the individual plant. The amount of nitrogen is generally much higher in leaves than in stems, leaf sheaths and roots, and it changes with plant age. More than a minimum level of nitrogen supply is necessary for $\mathrm{N}$ from vegetative parts to contribute to the formation of seed protein (Venekamps, Vries, \& Koot, 1985). Maize is an exhaustive crop and requires high quantities of nitrogen during the period of efficient utilization, for higher productivity. Nitrogen is indispensable for increasing crop production as a constituent of protoplasm and chlorophyll and is associated with the activity of every living cell. An increased response to applied nitrogen was observed in baby corn by Pandey, Mani, Prakash, Singh, and Gupta (2002). The application of 150:75:40 kg NPK ha ${ }^{-1}+10 \mathrm{t} \mathrm{FYM} \mathrm{was} \mathrm{found} \mathrm{to} \mathrm{be} \mathrm{optimal} \mathrm{for} \mathrm{obtaining} \mathrm{high} \mathrm{baby} \mathrm{corn} \mathrm{and} \mathrm{fodder} \mathrm{yields} \mathrm{with} \mathrm{good} \mathrm{quality}$ (Ramchandrappa et al., 2004). Application of NPK at 150:75:40 kg ha ${ }^{-1}+10$ ton farm yard manure (FYM) was found to be optimum for obtaining high baby corn and green fodder yields with good quality. The need to increase food production is one of the major world problems, where physical areas under cultivation cannot be increased. The only way is to increase the productivity per unit area per unit time. This can be achieved by changes of $\mathrm{N}$-fertilizer doses and by selecting suitable variety. But the information is meager on baby corn production in Bangladesh till now.

The present research work was, therefore, undertaken to evaluate the effect of $\mathrm{N}$ fertilizer rates for higher yield on the different varieties to be used for baby corn production.

\section{Method}

\subsection{Experimental Site and Climatic Condition}

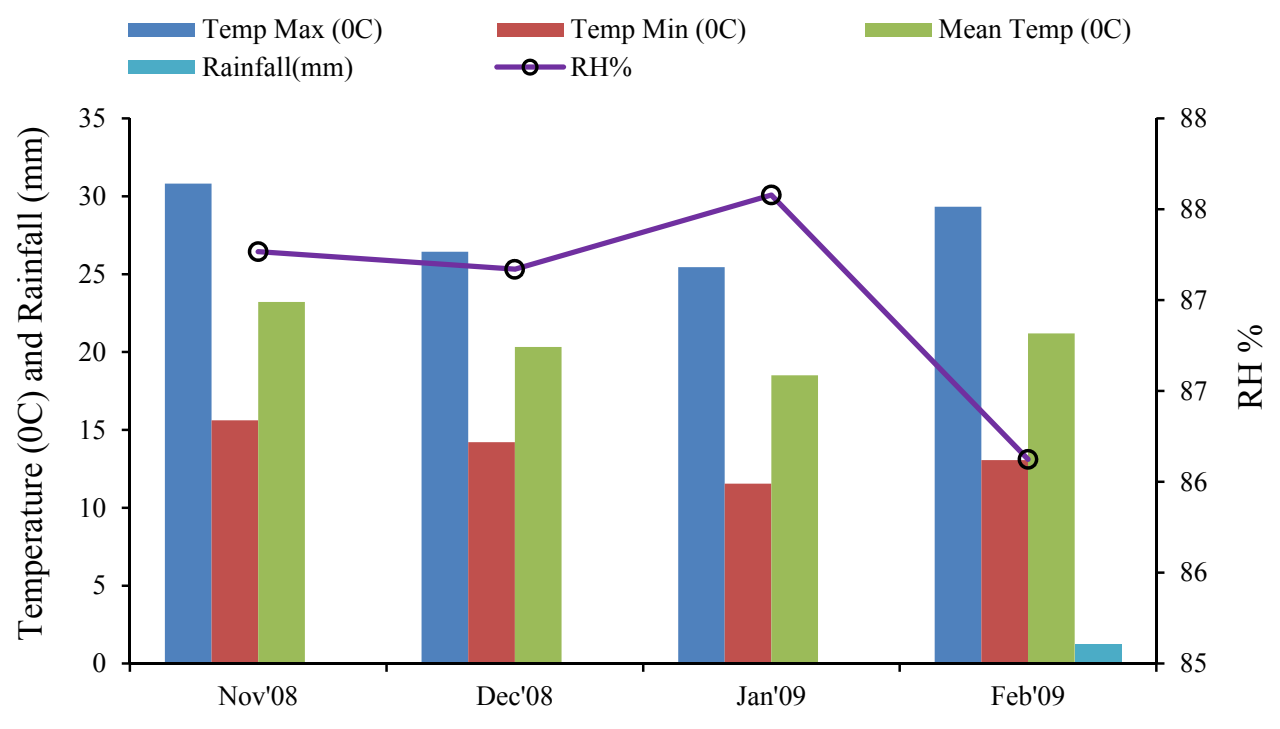

Months and year

Figure 1. Temperature, rainfall and relative humidity $(\mathrm{RH} \%)$ during the crop growing season from November 2008 to February 2009 
The experiment was conducted in 2008-09 at the Regional Station under Bangladesh Agricultural Research Institute (BARI) at Jamalpur in Bangladesh which is located at the Agro Ecological Zone-9 (AEZ-9) (UNDP \& FAO, 1988). The texture of the soil was silty loam. The land remained fallow before initiation of the experiment. The climate of the site was sub-tropical having the characteristics of scanty rainfall, low humidity, low temperature and short days during the rabi season. The average maximum $\left(23.2{ }^{\circ} \mathrm{C}\right)$ temperature was found in the month of November at early stage of crop establishment and minimum $\left(18.5^{\circ} \mathrm{C}\right)$ in the month of January during the crop growing season (Figure 1). The total rainfall was only $1.25 \mathrm{~mm}$ occurred in the month of February 2009 and there was no rainfall in the months of November, December and January during the growing season.

\subsection{Experimental Treatment and Cultivation Procedure}

There were four baby corn varieties viz. Hybrid baby corn-271( $\left.\mathrm{V}_{1}\right)$, BARI sweet corn-1 $\left(\mathrm{V}_{2}\right)$, BARI Khoibhutta $\left(\mathrm{V}_{3}\right)$ and Shuvra $\left(\mathrm{V}_{4}\right)$ and five $\mathrm{N}$ fertilizer rates viz. $0 \mathrm{~kg} \mathrm{~N} \mathrm{ha}^{-1}\left(\mathrm{~N}_{0}\right), 80 \mathrm{~kg} \mathrm{~N}^{-1}\left(\mathrm{~N}_{1}\right), 120 \mathrm{~kg} \mathrm{~N} \mathrm{ha}^{-1}\left(\mathrm{~N}_{2}\right), 160$ $\mathrm{kg} \mathrm{N} \mathrm{ha}{ }^{-1}\left(\mathrm{~N}_{3}\right)$ and $200 \mathrm{~kg} \mathrm{~N} \mathrm{ha}^{-1}\left(\mathrm{~N}_{4}\right)$ in the experiment. Fertilizers @ 125-80-125-8 kg ha ${ }^{-1}$ of TSP, MOP, Gypsum and Zinc Sulphate, respectively (BARI, 2004) were applied as blanket dose for all treatments during final land preparation. One-third $\mathrm{N}$ was applied as basal during final land preparation and the rest of $\mathrm{N}$ was top dressed in two equal splits at 25 and 45 days after emergence (DAE), respectively. The experiment was laid out in a split-plot design with three replications having unit plot size $4.5 \mathrm{~m} \times 3 \mathrm{~m}$ and assigning variety in the main plot and levels of $\mathrm{N}$ in the sub-plot. Seeds used in the experiment had more than $90 \%$ germination. Seeds were sown November 18, 2008 at the rate of $25 \mathrm{~kg} \mathrm{ha}^{-1}$ maintaining $50 \mathrm{~cm} \times 25 \mathrm{~cm}$ spacing. At first furrow was made with a tine and seeds were placed at 3-4 cm depth and then covered by light soil properly to ensure germination. Three irrigations were applied at 20,40 and 55 DAE. Weeding and thinning was done within 20 days of sowing before first irrigation. Plots were thinned to get desired stand at the seedling stage according to the principles of Vafias \& Ipsilandis (2005). Earthing-up was done within 45-50 days after second irrigation.

\subsection{Data Recorded}

Data were recorded on growth parameters like dry matter accumulation, crop growth rate (CGR), leaf area index (LAI), days to first tasseling and days to first silking.

CGR $\left(\mathrm{g} \mathrm{cm}^{-2} \mathrm{day}^{-1}\right)$, was calculated using equation as suggested by Yellamanda Reddy \& Sankara Reddi (2005) as follows.

$$
C G R=\frac{W_{2}-W_{1}}{t_{2}-t_{1}} \mathrm{gcm}^{-2} \text { day }^{-1}
$$

Where, $\mathrm{W}_{1}$ is the previous weight of plant, $\mathrm{W}_{2}$ is the final weight of plant, $\mathrm{t}_{1}$ is the time when previous weight of the plants was recorded, $t_{2}$ is the time when final weight of the plants was recorded.

The Leaf Area Index (LAI) was found by the equation as follows.

$$
L A I=\frac{\text { Total leaf area of the crop }}{\text { Total ground area under the crop }}
$$

Data were also collected on yield and yield parameters. Baby corn was harvested within 2-3 days of silking and corn yield was recorded with and without husk.

\subsection{Statistical Analysis}

Statistical analysis were done to compare the treatment means by using computer program MSTAT-C and mean separation was done at 5\% level of significance following Duncan's Multiple Range Test (DMRT).

\section{Results}

\subsection{Growth Parameters of Baby Corn}

\subsubsection{Effects of Variety on the Growth Parameters of Baby Corn}

The plant height was significantly different among the varieties at all growing stages (Figure 2). It increased sharply up to 80 DAE. Finally, Shuvra produced the tallest plant $(179.1 \mathrm{~cm})$ and BARI sweet corn-1 produced the shortest plant $(149.3 \mathrm{~cm})$. Days to first tasseling of different baby corn varieties also differed significantly (Table 1). Minimum days required for both tasseling and silking were found in Khoibhutta (66.7) which was statistically similar to BARI sweet corn-1 while maximum values were found in Hybrid baby corn-271. Total dry matter (TDM) accumulation plant ${ }^{-1}$ varied significantly among the varieties at all the growth periods (Figure 3). Shuvra produced the highest DM at all stages of growth except at 80 DAE. At 80 DAE Hybrid baby corn-271 
produced the highest DM. Khoibhutta had the lowest DM accumulation at all growth stages. Significant effect on CGR value at all growth periods was found among the varieties (Figure 4). A gradual increasing trend was recorded in CGR value with the advancement of growth periods. Hybrid baby corn-271 produced the highest CGR value at the period 0-20 and 50-65 DAE followed by Shuvra and Khoibhutta produced the lowest. On the other hand at 20-35 DAE Shuvra produced the highest CGR $\left(1.28 \mathrm{~g} \mathrm{~m}^{-2}\right.$ day $\left.^{-1}\right)$ and the lowest $\left(0.993 \mathrm{~g} \mathrm{~m}^{-2}\right.$ day $\left.^{-1}\right)$ was produced by BARI sweet corn-1 at the same period. Shuvra gave the highest LAI and the lowest was noted for BARI sweet corn-1 at all growth stages except at 0-20 DAE (Figure 5). At 0-20 DAE Khoibhutta gave the lowest LAI.

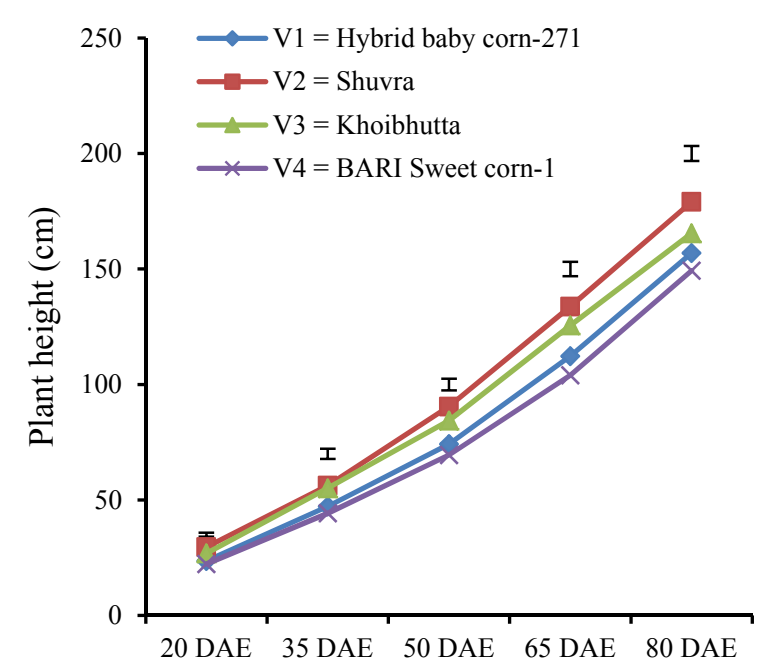

Figure 2. Plant height of different baby corn varieties at 15 day intervals

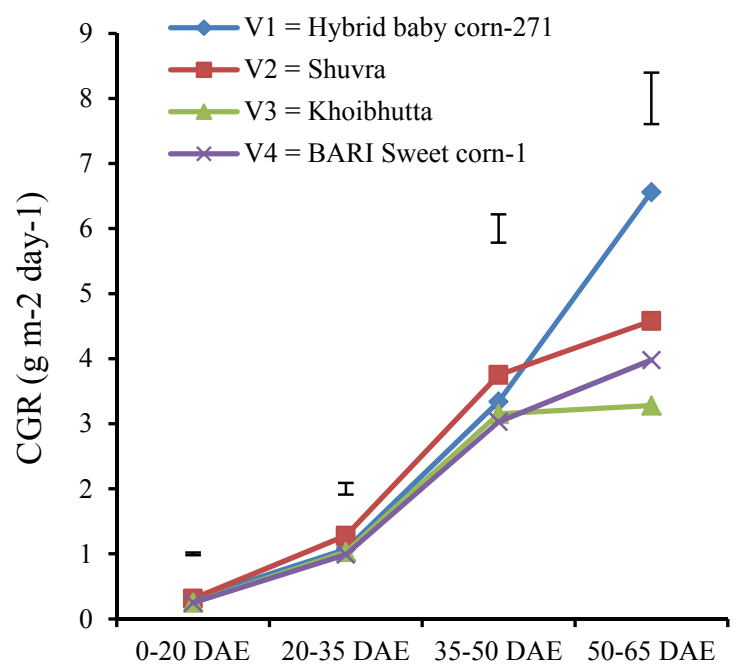

Figure 4. CGR of different baby corn varieties at 15 day intervals

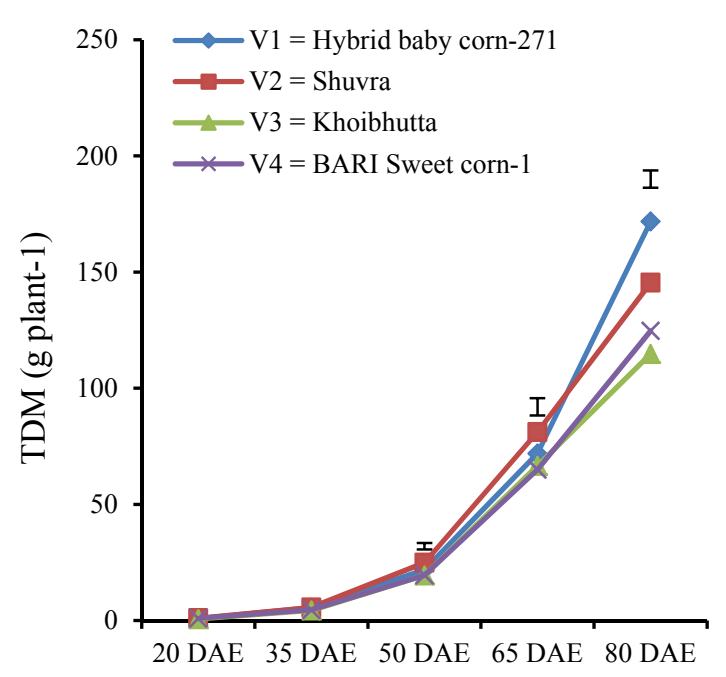

Figure 3. TDM of different baby corn varieties at 15 day intervals

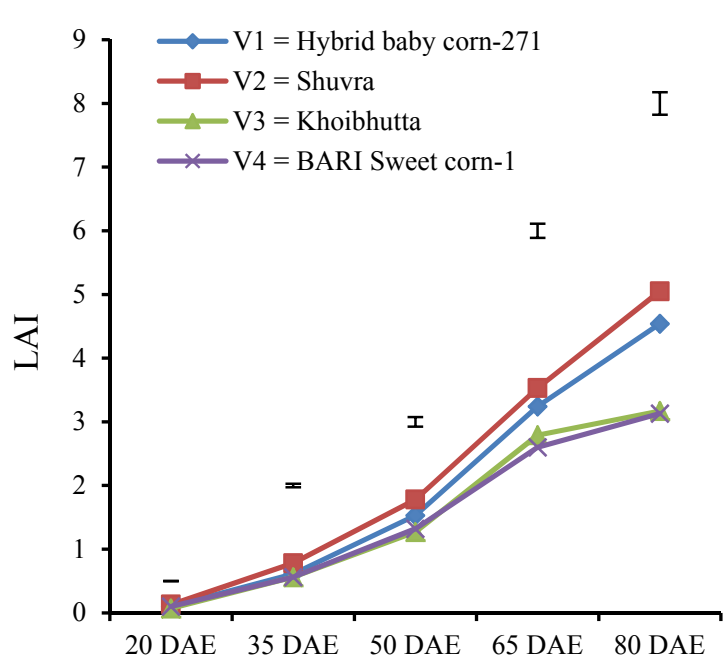

Figure 5. LAI of different baby corn varieties at 15 day intervals 
Table 1. Plant population $\mathrm{m}^{-2}$ at $10 \mathrm{DAS}$ and at harvest, days to first tasseling and days to first silking and period of harvest of different baby corn varieties as influenced by different $\mathrm{N}$ fertilizer doses during rabi, 2008-09

\begin{tabular}{lllll}
\hline Treatment & $\begin{array}{l}\text { Plant population } \mathrm{m}^{-2} \\
\text { at harvest }\end{array}$ & $\begin{array}{l}\text { Days to first } \\
\text { tasseling }\end{array}$ & $\begin{array}{l}\text { Days to first } \\
\text { silking }\end{array}$ & $\begin{array}{l}\text { Period of harvest } \\
\text { (days) }\end{array}$ \\
\hline Variety (V) & & & & \\
$\mathrm{V}_{1}$ & 6.9 & $82.1 \mathrm{a}$ & $86.3 \mathrm{a}$ & $5.3 \mathrm{c}$ \\
$\mathrm{V}_{2}$ & 6.7 & $80.4 \mathrm{~b}$ & $84.9 \mathrm{~b}$ & $5.6 \mathrm{c}$ \\
$\mathrm{V}_{3}$ & 6.4 & $66.7 \mathrm{c}$ & $71.2 \mathrm{c}$ & $9.3 \mathrm{a}$ \\
$\mathrm{V}_{4}$ & 6.9 & $66.7 \mathrm{c}$ & $71.3 \mathrm{c}$ & $7.8 \mathrm{~b}$ \\
Significance & $\mathrm{ns}$ & $* *$ & $* *$ & $* *$ \\
$\mathrm{CV} \%$ & 8.8 & 1.5 & 1.3 & 22.7 \\
$\mathrm{~N}$ fertilizer $(\mathrm{N})$ & & & & \\
$\mathrm{N}_{0}$ & $6.5 \mathrm{~b}$ & 73.9 & 78.3 & 7.5 \\
$\mathrm{~N}_{1}$ & $6.7 \mathrm{ab}$ & 74.0 & 78.3 & 6.8 \\
$\mathrm{~N}_{2}$ & $6.9 \mathrm{a}$ & 73.9 & 78.3 & 7.1 \\
$\mathrm{~N}_{3}$ & $6.6 \mathrm{~b}$ & 73.7 & 78.3 & 6.7 \\
$\mathrm{~N}_{4}$ & $7.0 \mathrm{a}$ & 74.3 & 78.8 & 7.0 \\
Significance & $* *$ & $\mathrm{~ns}$ & $\mathrm{~ns}$ & $\mathrm{~ns}$ \\
$\mathrm{CV} \%$ & 5.2 & 1.1 & 1.0 & 12.0 \\
\hline
\end{tabular}

Note: DAE=Days after emergence, $\mathrm{CV}=$ Coefficient of variation, $\mathrm{ns}=$ not significant, ${ }^{* *}$ Significant at $1 \%$ level. Figures in a column followed by same or no latter do not differ significantly at $5 \%$ level. $\mathrm{V}_{1}=$ Hybrid baby corn-271, $\mathrm{V}_{2}=$ Shuvra, $\mathrm{V}_{3}=$ Khoibhutta, $\mathrm{V}_{4}=$ BARI sweet corn- $1, \mathrm{~N}_{0}=0 \mathrm{~kg} \mathrm{~N} \mathrm{ha}^{-1}, \mathrm{~N}_{1}=80 \mathrm{~kg} \mathrm{~N}^{-1}, \mathrm{~N}_{2}=120 \mathrm{~kg}$ $\mathrm{N} \mathrm{ha}^{-1}, \mathrm{~N}_{3}=160 \mathrm{~kg} \mathrm{~N} \mathrm{ha}^{-1}, \mathrm{~N}_{4}=200 \mathrm{~kg} \mathrm{~N} \mathrm{ha}^{-1}$.

\subsubsection{Effects of N-Level on the Growth Parameters of Baby Corn}

$\mathrm{N}$-fertilizer had significant effect on plant height at all growth stages (Figure 6). At 65 DAE the maximum plant height was recorded at $160 \mathrm{~kg} \mathrm{~N} \mathrm{ha}^{-1}$ which was statistically similar to $200 \mathrm{~kg} \mathrm{~N}^{-1}$. In general, the tallest plant was observed at $200 \mathrm{~kg} \mathrm{~N} \mathrm{ha}^{-1}$ and the shortest at $0 \mathrm{~kg} \mathrm{~N} \mathrm{ha}^{-1}$ at all growth stages. There was no significant difference for days to fist tasseling and silking due to $\mathrm{N}$ fertilizer rates (Table 1). Significant variation was observed in respect of DM accumulation due to different $\mathrm{N}$ fertilizer rates at all growth stages (Figure 7) irrespective of varieties. Results revealed that dry matter accumulation increased sharply with the increase of $\mathrm{N}$-rates. There were no significant differences between 160 and $200 \mathrm{~kg} \mathrm{~N} \mathrm{ha}^{-1}$ in terms of DM accumulation except at 80 DAE. The lowest DM was recorded in $0 \mathrm{~kg} \mathrm{~N} \mathrm{ha}^{-1}$ at all growth stages and the differences of DM accumulation was higher in later than early stages. $\mathrm{N}$-fertilizer exerted significant influence on CGR values and it was inconsistent at all growth periods (Figure 8). The highest CGR value $\left(0.432 \mathrm{~g} \mathrm{~m}^{-2} \mathrm{day}^{-1}\right)$ was recorded at $200 \mathrm{~kg} \mathrm{~N} \mathrm{ha}^{-1}$ and the lowest was in $0 \mathrm{~kg} \mathrm{~N} \mathrm{ha}^{-1}$ at 0-20 DAE. At 20-35 and 35-50 DAE the highest CGR values were recorded in $160 \mathrm{~kg} \mathrm{~N} \mathrm{ha}^{-1}$ and the lowest in $0 \mathrm{~kg} \mathrm{~N} \mathrm{ha}^{-1}$. The highest CGR value was recorded with $200 \mathrm{~kg}$ $\mathrm{N} \mathrm{ha}^{-1}$ and the lowest in $0 \mathrm{~kg} \mathrm{~N} \mathrm{ha}^{-1}$ at 50-65 DAE. Significant variation was recorded in case of LAI due to N fertilizer doses (Figure 9). At all growth stages the highest LAI was obtained with $200 \mathrm{~kg} \mathrm{~N} \mathrm{ha}^{-1}$. On the contrary, $0 \mathrm{~kg} \mathrm{~N} \mathrm{ha}^{-1}$ recorded the lowest LAI at all growth stages. 


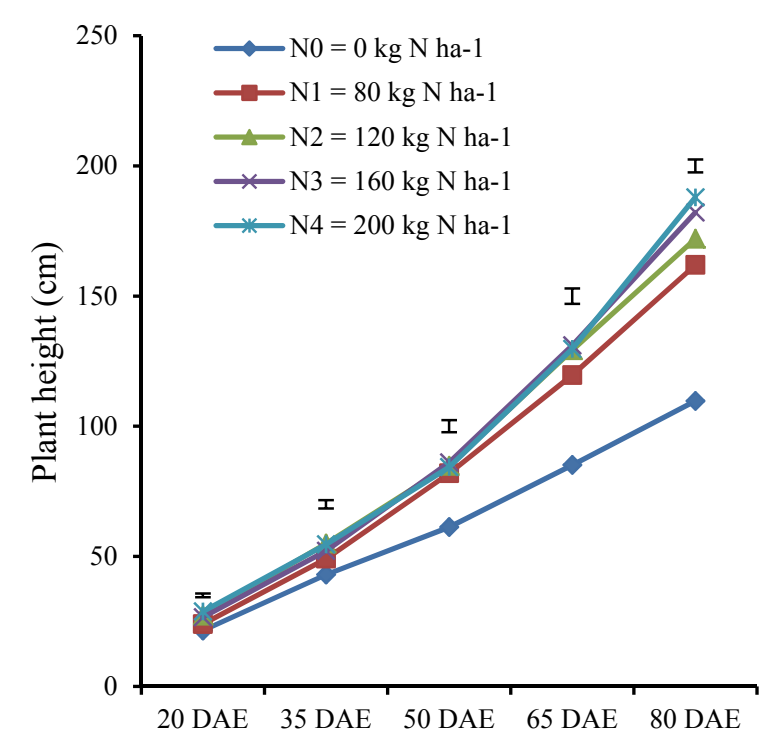

Figure 6. Plant height of different baby corn varieties as influenced by $\mathrm{N}$-fertilizer at 15 day intervals

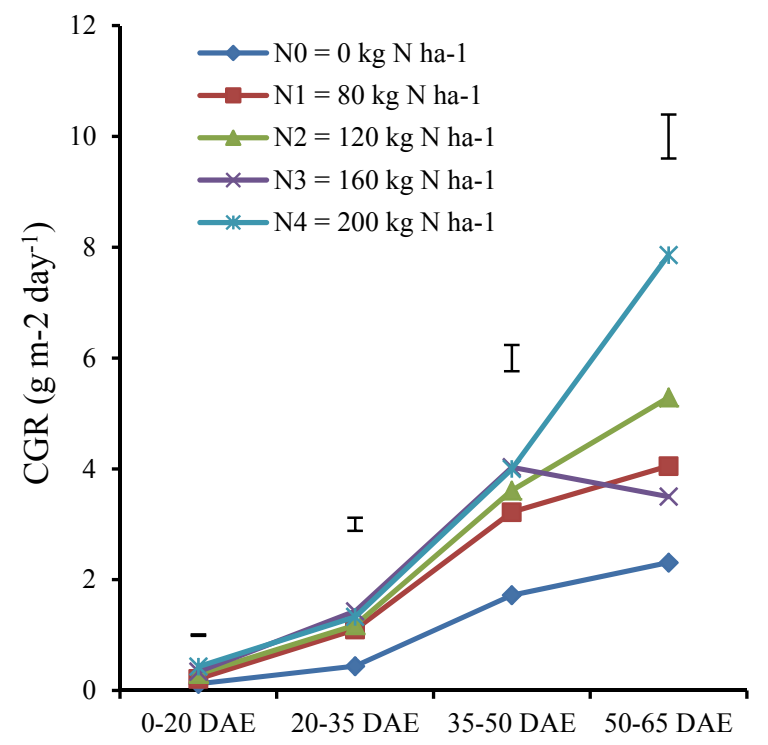

Figure 8. CGR of different baby corn varieties as influenced by $\mathrm{N}$-fertilizer doses at 15 day

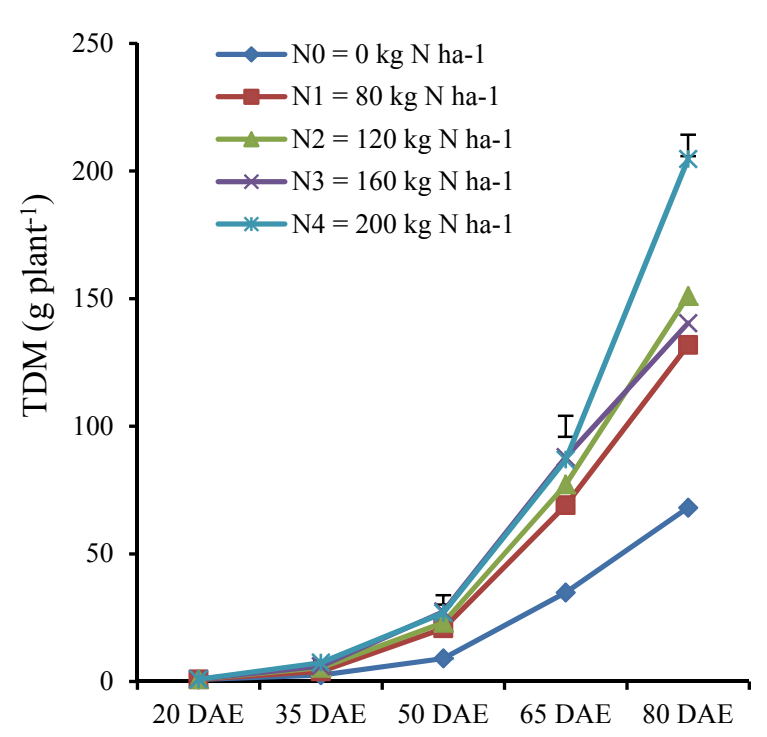

Figure 7. TDM of different baby corn varieties as influenced by $\mathrm{N}$-fertilizer at 15 day intervals

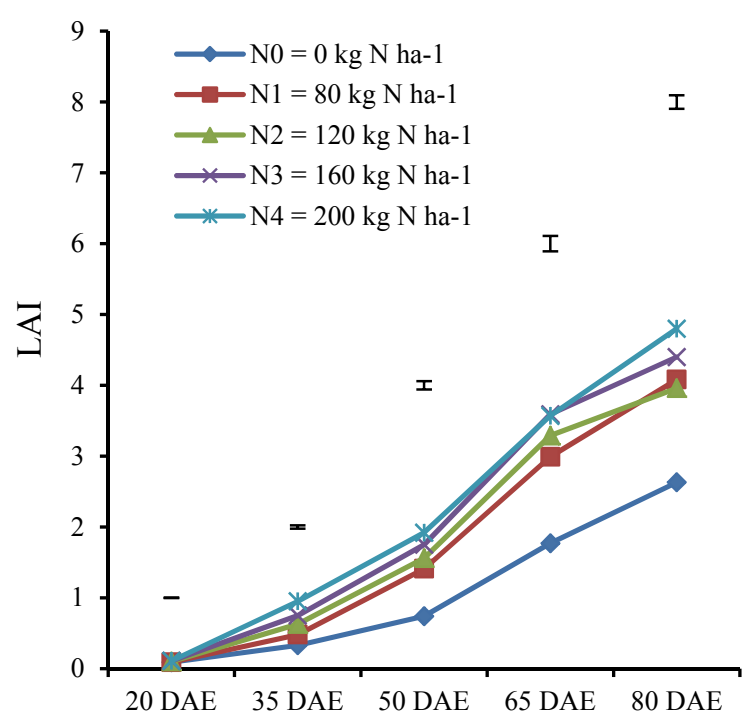

Figure 9. LAI of different varieties as influenced by $\mathrm{N}$-fertilizer doses at 15 day intervals

\subsubsection{Interaction of Variety and N-Level on the Growth Parameters of Baby Corn}

Interaction effects of variety and $\mathrm{N}$ fertilizer was found significant for plant height at all growth stages (Figure 10). The tallest plant was obtained from Shuvra at $200 \mathrm{~kg} \mathrm{~N} \mathrm{ha}^{-1}$ and the shortest from BARI sweet corn- 1 at 0 $\mathrm{kg} \mathrm{N} \mathrm{ha}{ }^{-1}$ at all growth stages. Interaction between variety and $\mathrm{N}$ fertilizer rates was found significant for days to first tasseling and first silking (Table 2). Hybrid baby corn-271 took maximum days (83.0) for tasseling with 200 $\mathrm{kg} \mathrm{N} \mathrm{ha}^{-1}$ whilst BARI sweet corn-1 at $160 \mathrm{~kg} \mathrm{~N} \mathrm{ha}^{-1}$ took the minimum (65.3). Hybrid baby corn-271 took maximum days (87.7) for silking with $200 \mathrm{~kg} \mathrm{~N} \mathrm{ha}^{-1}$ and BARI sweet corn-1 with $160 \mathrm{~kg} \mathrm{~N}^{-1}$ took the minimum days (70.0). In general, less period of harvest (5-6 days) was needed in Hybrid baby corn-271 and Shuvra compared to Khoibhutta and BARI sweet corn-1 (7-10 days) at all rates of N-fertilizer. Interaction of 
variety and different $\mathrm{N}$ fertilizer rates exerted significant variation on $\mathrm{DM}$ accumulation at all growth periods (Figure 11). Shuvra produced the maximum DM at all growing stages except at 35 and 80 DAE with the application of 120- $200 \mathrm{~kg} \mathrm{~N}^{-1} \mathrm{a}^{-1}$. At 35 and 80 DAE Hybrid baby corn-271 had the highest TDM with 160 and $200 \mathrm{~kg} \mathrm{~N} \mathrm{ha}^{-1}$, respectively. The minimum DM accumulation was found with $0 \mathrm{~kg} \mathrm{~N} \mathrm{ha}^{-1}$ in all varieties at different growth stages but the values were inconsistent. The lowest DM accumulation at 20 and 35 were obtained in Khoibhutta and BARI sweet corn-1 while at 50 and 65 DAE in Baby corn-271 and at 80 DAE in Khoibhutta with $0 \mathrm{~kg} \mathrm{~N} \mathrm{ha}^{-1}$. Interaction of variety and $\mathrm{N}$-fertilizer produced significant influence on CGR values at all growth periods (Figure 12). CGR values were minimum at all growth periods with $0 \mathrm{~kg} \mathrm{~N}^{-1}$ in all varieties. At 0-20 DAE the highest CGR value was recorded with $200 \mathrm{~kg} \mathrm{~N} \mathrm{ha}^{-1}$ in Shuvra and the lowest was recorded in BARI sweet corn-1 with $0 \mathrm{~kg} \mathrm{~N} \mathrm{ha}^{-1}$. At 20-35 and 35-50 DAE the highest CGR values were recorded with $160 \mathrm{~kg} \mathrm{~N} \mathrm{ha}^{-1}$ in Shuvra and the lowest in Baby corn-271 at $0 \mathrm{~kg} \mathrm{~N} \mathrm{ha}^{-1}$. The highest CGR value was recorded in Baby corn-271 at 50-65 DAE followed by Shuvra with $200 \mathrm{~kg} \mathrm{~N}^{-1}$ while the lowest in Khoibhutta at $0 \mathrm{~kg} \mathrm{~N} \mathrm{ha}^{-1}$. Interaction effects of variety and $\mathrm{N}$ fertilizer rates on LAI were found highly significant at all plant growth stages (Figure 13). Shuvra gave the highest LAI values with $200 \mathrm{~kg} \mathrm{~N}^{-1}$ at all growth stages but not at $65 \mathrm{DAE}$. At $65 \mathrm{DAE}$, Shuvra gave the highest LAI with $160 \mathrm{~kg} \mathrm{~N} \mathrm{ha}^{-1}$. From the Figure 13 it was observed that all varieties showed the lowest LAI values with $0 \mathrm{~kg} \mathrm{~N} \mathrm{ha}^{-1}$ at all growth stages.

Table 2. Plant population $\mathrm{m}^{-2}$ at 10 DAS and at harvest, days to first tasseling and days to first silking and period of harvest of different baby corn varieties as influenced by different $\mathrm{N}$ fertilizer doses during rabi, 2008-09

\begin{tabular}{|c|c|c|c|c|}
\hline $\begin{array}{l}\text { Interaction } \\
(\mathrm{V} \times \mathrm{N})\end{array}$ & $\begin{array}{l}\text { Plant population } \mathrm{m}^{-2} \text { at } \\
\text { harvest }\end{array}$ & $\begin{array}{l}\text { Days to first } \\
\text { tasseling }\end{array}$ & $\begin{array}{l}\text { Days to first } \\
\text { silking }\end{array}$ & $\begin{array}{l}\text { Period of harvest } \\
\text { (days) }\end{array}$ \\
\hline $\mathrm{V}_{1} \mathrm{~N}_{0}$ & 6.9 & $82.3 \mathrm{ab}$ & $86.3 \mathrm{ab}$ & $5.0 \mathrm{~h}$ \\
\hline $\mathrm{V}_{1} \mathrm{~N}_{1}$ & 6.5 & $81.3 \mathrm{bc}$ & $85.3 \mathrm{bc}$ & $5.7 \mathrm{f}-\mathrm{h}$ \\
\hline $\mathrm{V}_{1} \mathrm{~N}_{2}$ & 7.2 & $81.3 \mathrm{bc}$ & $85.7 \mathrm{~b}$ & $5.3 \mathrm{gh}$ \\
\hline $\mathrm{V}_{1} \mathrm{~N}_{3}$ & 6.8 & $82.3 \mathrm{ab}$ & $86.3 \mathrm{~b}$ & $5.3 \mathrm{gh}$ \\
\hline $\mathrm{V}_{1} \mathrm{~N}_{4}$ & 7.1 & $83.0 \mathrm{a}$ & $87.7 \mathrm{a}$ & $5.3 \mathrm{gh}$ \\
\hline $\mathrm{V}_{2} \mathrm{~N}_{0}$ & 6.4 & $80.7 \mathrm{~cd}$ & $85.0 \mathrm{bc}$ & $5.7 \mathrm{f}-\mathrm{h}$ \\
\hline $\mathrm{V}_{2} \mathrm{~N}_{1}$ & 6.9 & $81.0 \mathrm{~b}-\mathrm{d}$ & $85.3 \mathrm{bc}$ & $5.7 \mathrm{f}-\mathrm{h}$ \\
\hline $\mathrm{V}_{2} \mathrm{~N}_{2}$ & 6.3 & $79.7 \mathrm{~d}$ & $84.0 \mathrm{c}$ & $5.3 \mathrm{gh}$ \\
\hline $\mathrm{V}_{2} \mathrm{~N}_{3}$ & 6.7 & $80.3 \mathrm{~cd}$ & $85.0 \mathrm{bc}$ & $5.7 \mathrm{f}-\mathrm{h}$ \\
\hline $\mathrm{V}_{2} \mathrm{~N}_{4}$ & 7.2 & $80.3 \mathrm{~cd}$ & $85.0 \mathrm{bc}$ & $5.7 \mathrm{f}-\mathrm{h}$ \\
\hline $\mathrm{V}_{3} \mathrm{~N}_{0}$ & 6.1 & $66.0 \mathrm{gh}$ & $70.3 \mathrm{ef}$ & $9.0 \mathrm{a}-\mathrm{c}$ \\
\hline $\mathrm{V}_{3} \mathrm{~N}_{1}$ & 6.4 & $66.3 \mathrm{f}-\mathrm{h}$ & $71.0 \mathrm{~d}-\mathrm{f}$ & $8.7 \mathrm{~b}-\mathrm{d}$ \\
\hline $\mathrm{V}_{3} \mathrm{~N}_{2}$ & 6.9 & $66.7 \mathrm{e}-\mathrm{h}$ & $71.3 \mathrm{~d}-\mathrm{f}$ & $10.0 \mathrm{ab}$ \\
\hline $\mathrm{V}_{3} \mathrm{~N}_{3}$ & 6.2 & $66.7 \mathrm{e}-\mathrm{h}$ & $71.7 \mathrm{de}$ & $8.7 \mathrm{~b}-\mathrm{d}$ \\
\hline $\mathrm{V}_{3} \mathrm{~N}_{4}$ & 6.6 & $67.7 \mathrm{ef}$ & $71.7 \mathrm{de}$ & $10.3 \mathrm{a}$ \\
\hline $\mathrm{V}_{4} \mathrm{~N}_{0}$ & 6.5 & $66.7 \mathrm{e}-\mathrm{h}$ & $71.7 \mathrm{de}$ & $10.3 \mathrm{a}$ \\
\hline $\mathrm{V}_{4} \mathrm{~N}_{1}$ & 7.2 & $67.3 \mathrm{e}-\mathrm{g}$ & $71.3 \mathrm{~d}-\mathrm{f}$ & $7.3 \mathrm{de}$ \\
\hline $\mathrm{V}_{4} \mathrm{~N}_{2}$ & 7.2 & $68.0 \mathrm{e}$ & $72.3 \mathrm{~d}$ & $7.7 \mathrm{c}-\mathrm{e}$ \\
\hline $\mathrm{V}_{4} \mathrm{~N}_{3}$ & 6.6 & $65.3 \mathrm{~h}$ & $70.0 \mathrm{f}$ & $7.0 \mathrm{ef}$ \\
\hline $\mathrm{V}_{4} \mathrm{~N}_{4}$ & 7.2 & $66.0 \mathrm{gh}$ & $71.0 \mathrm{~d}-\mathrm{f}$ & $6.7 \mathrm{e}-\mathrm{g}$ \\
\hline Significance & ns & $* *$ & $* *$ & $* *$ \\
\hline $\mathrm{CV} \%$ & 5.2 & 1.1 & 1.0 & 12.0 \\
\hline
\end{tabular}

Note: $\mathrm{DAE}=$ Days after emergence, $\mathrm{CV}=$ Coefficient of variation, $\mathrm{ns}=$ not significant, ${ }^{* *}$ Significant at $1 \%$ level. Figures in a column followed by same or no latter do not differ significantly at $5 \%$ level. $\mathrm{V}_{1}=$ Hybrid baby corn-271, $\mathrm{V}_{2}=$ Shuvra, $\mathrm{V}_{3}=$ Khoibhutta, $\mathrm{V}_{4}=$ BARI sweet corn- $1, \mathrm{~N}_{0}=0 \mathrm{kgN} \mathrm{ha}{ }^{-1}, \mathrm{~N}_{1}=80 \mathrm{kgN} \mathrm{ha}^{-1}, \mathrm{~N}_{2}=120$ $\mathrm{kgN} \mathrm{ha}^{-1}, \mathrm{~N}_{3}=160 \mathrm{kgN} \mathrm{ha}^{-1}, \mathrm{~N}_{4}=200 \mathrm{kgN} \mathrm{ha}^{-1}$. 


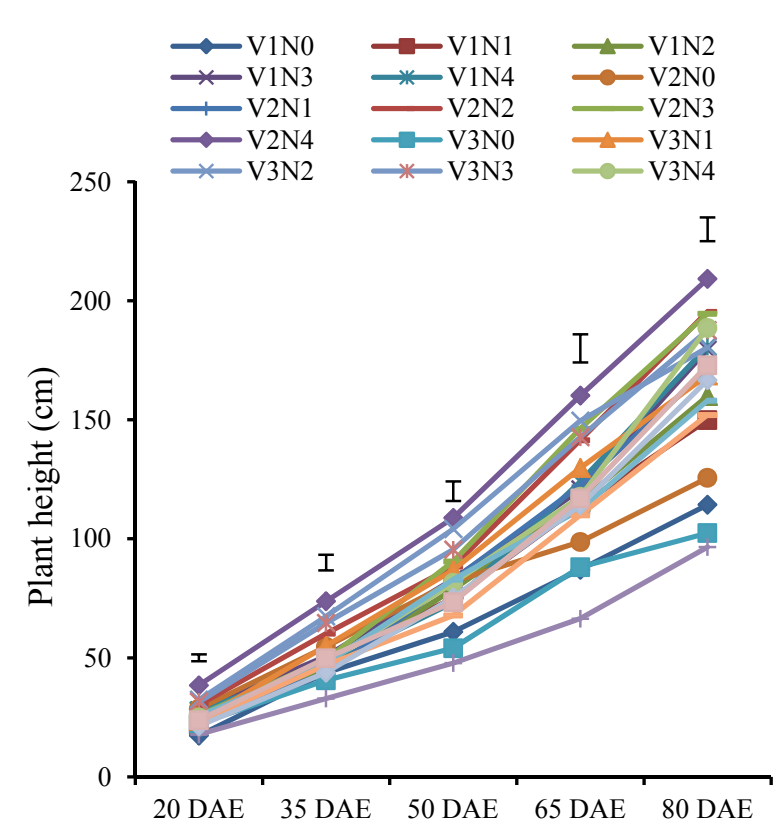

Figure 10. Interaction effect of different varieties and $\mathrm{N}$-fertilizer on plant height at 15 day intervals

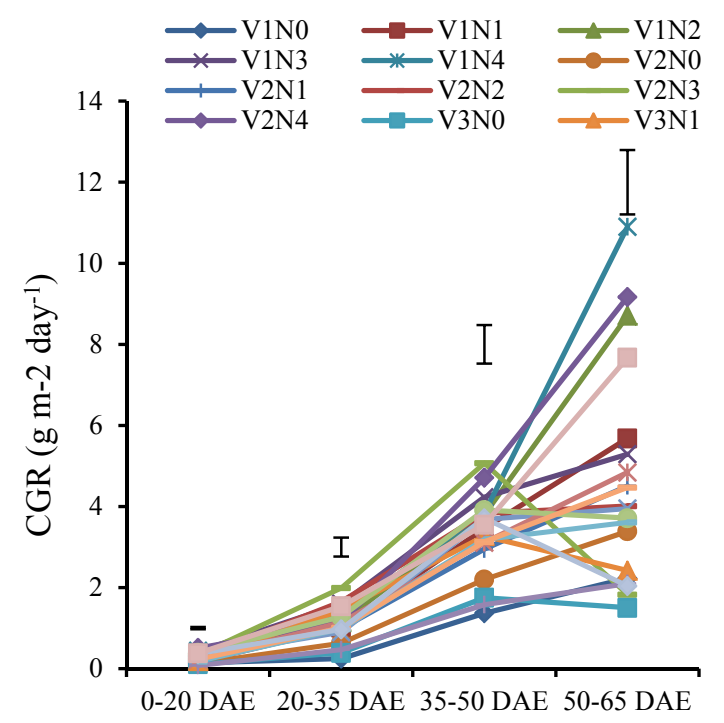

Figure 12. Interaction effect of varieties and Nfertilizer doses on CGR at 15 day intervals

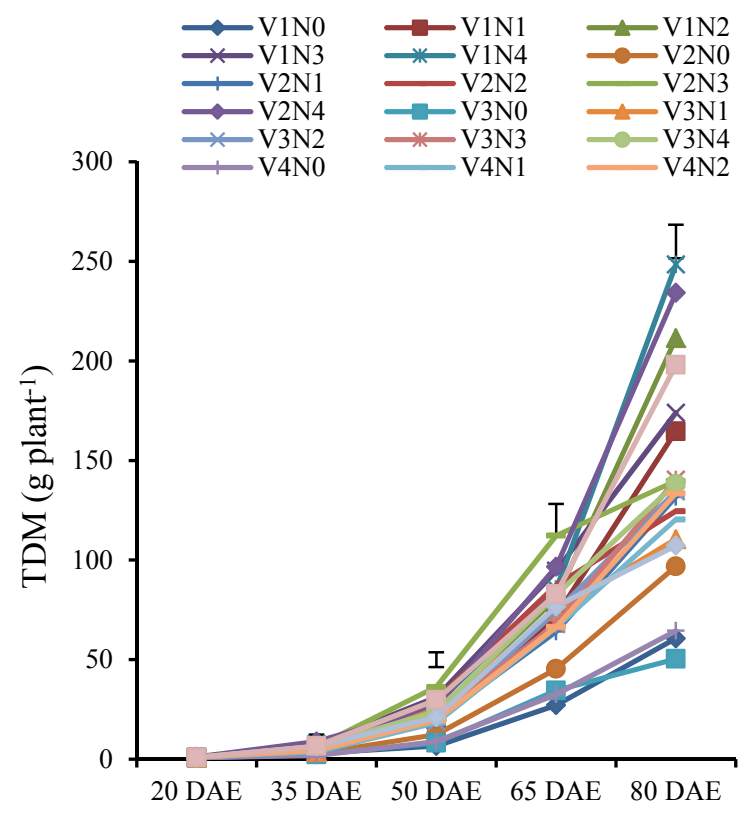

Figure 11. Interaction effect of varieties and $\mathrm{N}$-fertilizer on TDM at 15 day intervals

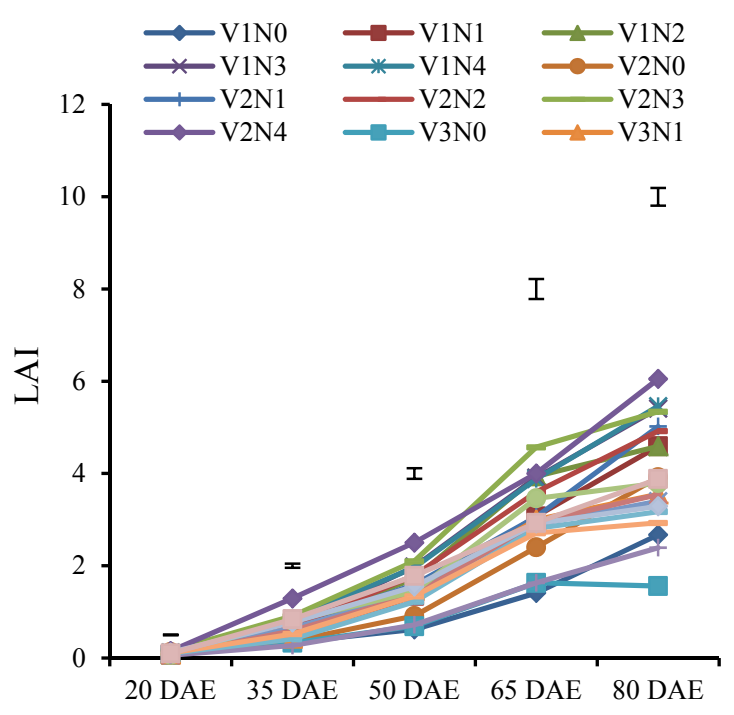

Figure 13. Interaction effect of varieties and Nfertilizer doses on LAI at 15 day intervals

\subsection{Yield and Yield Components of Baby Corn}

\subsubsection{Effects of Variety on the Yield and Yield Components of Baby Corn}

Number of ear plant ${ }^{-1}$ of baby corn varieties differed significantly among the varieties (Table 3 ). The maximum ears plant ${ }^{-1}$ (2.2) was recorded in Hybrid Baby Corn-271 and the minimum (1.4) was in Shuvra. Length of ear also varied significantly having the longest ear $(10.8 \mathrm{~cm})$ in Shuvra and the shortest $(9.6 \mathrm{~cm})$ in BARI sweet corn-1 (Table 3). Performance of baby corn varieties was statistically significant in case of ear diameter (Table 3). The maximum ear diameter $(1.7 \mathrm{~cm})$ was found in Shuvra and minimum $(1.4 \mathrm{~cm})$ was found in Khoibhutta which was statistically similar to Hybrid Baby Corn-1. Significantly highest corn yield without husk $\left(1.9 \mathrm{t} \mathrm{ha}^{-1}\right)$ was obtained from BARI sweet corn-1 which was statistically similar to Hybrid Baby Corn-271 $\left(1.8 \mathrm{tha}^{-1}\right)$ and Khoibhutta $\left(1.8 \mathrm{tha}^{-1}\right)$ and the minimum ear yield $\left(1.7 \mathrm{tha}^{-1}\right)$ without husk was recorded in Shuvra. The ear yield 
with husk of baby corn was statistically significant (Table 3) and it was found that the maximum ear yield with husk $\left(12.8 \mathrm{tha}^{-1}\right)$ was recorded in Hybrid Baby Corn-271 and the minimum $\left(9.7 \mathrm{tha}^{-1}\right)$ was recorded in Shuvra. Varieties Khoibhutta and BARI sweet corn-1 produced significantly different corn yield with husk from those of Hybrid baby corn-271 and Shuvra. BARI sweet corn-1 produced the second highest baby corn yield with husk $\left(12.1 \mathrm{t} \mathrm{ha}^{-1}\right)$. Significant difference was observed (Table 3) in respect of fodder yield and the highest fodder yield $\left(32.1 \mathrm{t} \mathrm{ha}^{-1}\right)$ was found in Shuvra followed by Hybrid Baby Corn-271 $\left(29.5 \mathrm{t} \mathrm{ha}^{-1}\right)$. The lowest fodder yield $(25.4$ $\mathrm{t} \mathrm{ha}^{-1}$ ) was recorded in BARI Sweet Corn-1.

\subsubsection{Effects of N-Rate on the Yield and Yield Components of Baby Corn}

The $\mathrm{N}$ fertilizer rates showed significant difference in case of ear plant ${ }^{-1}$, ear length, corn yield without husk and with husk, and fodder yield (Table 3). Number of ear plant ${ }^{-1}$ increased sharply with the increment of $\mathrm{N}$-fertilizer rates and the highest number of ear $\operatorname{plant}^{-1}(2.3)$ was recorded at $200 \mathrm{~kg} \mathrm{~N} \mathrm{ha}^{-1}$ which was significantly different from those of others $\mathrm{N}$-fertilizer rates. The lowest number of ear plant ${ }^{-1}(1.3)$ was recorded at $0 \mathrm{~kg} \mathrm{~N} \mathrm{ha}^{-1}$. The maximum ear length $(10.5 \mathrm{~cm})$ was found at $200 \mathrm{~kg} \mathrm{~N}^{-1}$ similar to all other $\mathrm{N}$-rates but except $0 \mathrm{~kg} \mathrm{~N} \mathrm{ha}{ }^{-1}$. The minimum ear length $(9.5 \mathrm{~cm})$ was found at $0 \mathrm{~kg} \mathrm{~N} \mathrm{ha}^{-1}$. The effect of $\mathrm{N}$ fertilizer rates on ear diameter was found non-significant. Baby corn yield without husk increased gradually with higher rates of $\mathrm{N}$ but the increment was not significant beyond $160 \mathrm{~kg} \mathrm{~N} \mathrm{ha}^{-1}$. Statistically similar baby corn yield $\left(2.1 \mathrm{t} \mathrm{ha}^{-1}\right)$ was obtained from 160 and $200 \mathrm{~kg} \mathrm{~N} \mathrm{ha}^{-1}$. The lowest baby corn yield without husk $\left(1.0 \mathrm{tha}^{-1}\right)$ was found at $0 \mathrm{~kg} \mathrm{~N} \mathrm{ha}^{-1}$ which was significantly different from others. The highest ear yield $\left(14.6 \mathrm{tha}^{-1}\right)$ with husk was recorded at $200 \mathrm{~kg} \mathrm{~N} \mathrm{ha}^{-1}$ which was significantly different from other rates and the lowest was found at $0 \mathrm{~kg} \mathrm{~N} \mathrm{ha}^{-1}\left(5.7 \mathrm{t} \mathrm{ha}^{-1}\right)$. The results revealed that fodder yield increased with increased rates of $\mathrm{N}$ and finally $200 \mathrm{~kg} \mathrm{~N}^{-1}$ produced the highest fodder yield $\left(32.6 \mathrm{tha}^{-1}\right)$ whilst $0 \mathrm{~kg} \mathrm{~N}^{-1}$ produced the lowest $\left(19.5 \mathrm{t} \mathrm{ha}^{-1}\right)$.

Table 3. Ear yield, yield attributes and fodder yield of different baby corn varieties as influenced by different $\mathrm{N}$ fertilizer rates

\begin{tabular}{lllllll}
\hline Treatment & $\begin{array}{l}\text { Ear } \\
\text { plant }\end{array}$ & $\begin{array}{l}\text { Ear length } \\
(\mathrm{cm})\end{array}$ & $\begin{array}{l}\text { Ear diameter } \\
(\mathrm{cm})\end{array}$ & $\begin{array}{l}\text { Yield without } \\
\text { husk }\left(\mathrm{t} \mathrm{ha}^{-1}\right)\end{array}$ & $\begin{array}{l}\text { Yield with } \\
\text { husk }\left(\mathrm{t} \mathrm{ha}^{-1}\right)\end{array}$ & $\begin{array}{l}\text { Fodder yield } \\
\left(\mathrm{t} \mathrm{ha}^{-1}\right)\end{array}$ \\
\hline Variety (V) & & & & & & \\
$\mathrm{V}_{1}$ & $2.2 \mathrm{a}$ & $10.0 \mathrm{bc}$ & $1.5 \mathrm{~b}$ & $1.8 \mathrm{a}$ & $12.8 \mathrm{a}$ & $29.5 \mathrm{~b}$ \\
$\mathrm{~V}_{2}$ & $1.4 \mathrm{c}$ & $10.8 \mathrm{a}$ & $1.7 \mathrm{a}$ & $1.7 \mathrm{~b}$ & $9.7 \mathrm{~d}$ & $32.1 \mathrm{a}$ \\
$\mathrm{V}_{3}$ & $2.0 \mathrm{~b}$ & $10.3 \mathrm{~b}$ & $1.4 \mathrm{~b}$ & $1.8 \mathrm{a}$ & $10.8 \mathrm{c}$ & $27.0 \mathrm{c}$ \\
$\mathrm{V}_{4}$ & $2.1 \mathrm{ab}$ & $9.6 \mathrm{c}$ & $1.5 \mathrm{ab}$ & $1.9 \mathrm{a}$ & $12.1 \mathrm{~b}$ & $25.4 \mathrm{~d}$ \\
Significance & $* *$ & $* *$ & $*$ & $*$ & $* *$ & $* *$ \\
$\mathrm{CV} \%$ & 10.6 & 4.9 & 11.2 & 8.4 & 6.2 & 6.0 \\
$\mathrm{~N}$ fertilizer & & & & & & \\
$(\mathrm{N})$ & & & & $1.0 \mathrm{~d}$ & $5.7 \mathrm{e}$ & $19.5 \mathrm{e}$ \\
$\mathrm{N}_{0}$ & $1.3 \mathrm{e}$ & $9.5 \mathrm{~b}$ & 1.5 & $1.8 \mathrm{c}$ & $11.2 \mathrm{~d}$ & $28.9 \mathrm{~d}$ \\
$\mathrm{~N}_{1}$ & $1.8 \mathrm{~d}$ & $10.2 \mathrm{a}$ & 1.5 & $2.0 \mathrm{~b}$ & $12.0 \mathrm{c}$ & $30.3 \mathrm{c}$ \\
$\mathrm{N}_{2}$ & $2.0 \mathrm{c}$ & $10.4 \mathrm{a}$ & 1.5 & $2.1 \mathrm{a}$ & $13.2 \mathrm{~b}$ & $31.2 \mathrm{~b}$ \\
$\mathrm{~N}_{3}$ & $2.1 \mathrm{~b}$ & $10.2 \mathrm{a}$ & 1.5 & $2.1 \mathrm{a}$ & $14.6 \mathrm{a}$ & $32.6 \mathrm{a}$ \\
$\mathrm{N}_{4}$ & $2.3 \mathrm{a}$ & $10.5 \mathrm{a}$ & 1.5 & $* *$ & $* *$ & $* *$ \\
Significance & $* *$ & $* *$ & $\mathrm{~ns}$ & 6.6 & 5.0 & 2.3 \\
$\mathrm{CV} \%$ & 5.5 & 4.4 & 6.2 & 6 & & \\
\hline
\end{tabular}

Note: DAE=Days after emergence, $\mathrm{CV}=$ Coefficient of variation, $\mathrm{ns}=$ not significant, *Significant at $5 \%$ level, **Significant at $1 \%$ level. Figures in a column followed by same or no latter do not differ significantly at $5 \%$ level. $\mathrm{V}_{1}=$ Hybrid baby corn-271, $\mathrm{V}_{2}=$ Shuvra, $\mathrm{V}_{3}=$ Khoibhutta, $\mathrm{V}_{4}=$ BARI sweet corn- $1, \mathrm{~N}_{0}=0 \mathrm{kgN}$ ha ${ }^{-1}, \mathrm{~N}_{1}=$ $80 \mathrm{kgN} \mathrm{ha}^{-1}, \mathrm{~N}_{2}=120 \mathrm{kgN} \mathrm{ha}^{-1}, \mathrm{~N}_{3}=160 \mathrm{kgN} \mathrm{ha}^{-1}, \mathrm{~N}_{4}=200 \mathrm{kgN} \mathrm{ha}^{-1}$.

\subsubsection{Interaction of Variety and N-Level on the Yield and Yield Components of Baby Corn}

The interaction effect of baby corn varieties and $\mathrm{N}$ fertilizer rate was statistically significant in case of all parameters studied except ear diameter (Table 4). In general, higher number of ear plant ${ }^{-1}$ was found in the varieties Hybrid baby corn-271, Khoibhutta and BARI sweet corn-1 compared to Shuvra with all rates of 
N-fertilizer. The maximum ear plant ${ }^{-1}(2.6)$ was recorded in Hybrid Baby Corn-271 at $200 \mathrm{~kg} \mathrm{~N}^{-1}$ and the minimum ear plant ${ }^{-1}(1.0)$ was recorded in Shuvra at $0 \mathrm{~kg} \mathrm{~N} \mathrm{ha}^{-1}$. Ear length increased significantly with the application of increased rates of $\mathrm{N}$-fertilizer. The longest ear $(11.3 \mathrm{~cm})$ was observed in Shuvra at $160 \mathrm{~kg} \mathrm{~N} \mathrm{ha}^{-1}$ and the shortest $(8.8 \mathrm{~cm})$ in BARI Sweet Corn- 1 at $0 \mathrm{~kg} \mathrm{~N} \mathrm{ha}^{-1}$. The highest baby corn yield $\left(2.23 \mathrm{tha}^{-1}\right)$ without husk was recorded in Hybrid Baby Corn-271 at $160 \mathrm{~kg} \mathrm{~N}$ ha $^{-1}$ and the lowest baby corn yield $\left(0.84 \mathrm{t} \mathrm{ha}^{-1}\right)$ was recorded in Shuvra similar to that of Hybrid Baby Corn-271 at $0 \mathrm{~kg} \mathrm{~N}^{-1}$. Baby corn yield without husk did not increase significantly beyond $160 \mathrm{~kg} \mathrm{~N} \mathrm{ha}^{-1}$ in Hybrid baby corn-271 and Shuvra. Contrary on this, baby corn yield without husk did not increase significantly beyond $120 \mathrm{~kg} \mathrm{~N}^{-1}$ in Khoibhutta and BARI sweet corn-1. The highest baby corn yield (18.04 $\mathrm{t} \mathrm{ha}^{-1}$ ) with husk was recorded in Hybrid baby corn-271 at $200 \mathrm{~kg} \mathrm{~N} \mathrm{ha}^{-1}$ and the lowest $\left(4.26 \mathrm{tha}^{-1}\right)$ in Shuvra at $0 \mathrm{~kg} \mathrm{~N} \mathrm{ha}^{-1}$. Significantly highest fodder yield $\left(36.10 \mathrm{t} \mathrm{ha}^{-1}\right)$ was recorded in Shuvra with $200 \mathrm{~kg} \mathrm{~N} \mathrm{ha}^{-1}$ whilst the lowest fodder yield $\left(16.0 \mathrm{t} \mathrm{ha}^{-1}\right)$ was recorded in BARI sweet corn-1 with 0 $\mathrm{kg} \mathrm{N} \mathrm{ha}{ }^{-1}$.

Table 4. Ear yield, yield attributes and fodder yield of different baby corn varieties as influenced by different $\mathrm{N}$ fertilizer doses during rabi, 2008-09

\begin{tabular}{|c|c|c|c|c|c|c|}
\hline $\begin{array}{l}\text { Interaction } \\
(\mathrm{V} \times \mathrm{N})\end{array}$ & $\begin{array}{l}\text { Ear } \\
\text { plant }^{-1}\end{array}$ & $\begin{array}{l}\text { Ear length } \\
(\mathrm{cm})\end{array}$ & $\begin{array}{l}\text { Ear diameter } \\
(\mathrm{cm})\end{array}$ & $\begin{array}{l}\text { Yield without } \\
\text { husk }\left(\mathrm{t} \mathrm{ha}^{-1}\right)\end{array}$ & $\begin{array}{l}\text { Yield with } \\
\text { husk }\left(\mathrm{t} \mathrm{ha}^{-1}\right)\end{array}$ & $\begin{array}{l}\text { Fodder yield } \\
\left(\mathrm{t} \mathrm{ha}^{-1}\right)\end{array}$ \\
\hline $\mathrm{V}_{1} \mathrm{~N}_{0}$ & $1.4 \mathrm{~h}$ & 9.0 ef & 1.5 & $0.94 \mathrm{i}$ & $5.89 \mathrm{j}$ & 20.831 \\
\hline $\mathrm{V}_{1} \mathrm{~N}_{1}$ & $2.1 \mathrm{~d}-\mathrm{f}$ & $10.1 \mathrm{~cd}$ & 1.4 & $1.78 \mathrm{ef}$ & $11.39 \mathrm{~g}$ & $29.80 \mathrm{~g}$ \\
\hline $\mathrm{V}_{1} \mathrm{~N}_{2}$ & $2.2 \mathrm{c}-\mathrm{e}$ & $10.3 \mathrm{~b}-\mathrm{d}$ & 1.5 & $1.96 \mathrm{c}-\mathrm{e}$ & $13.00 \mathrm{de}$ & $31.43 \mathrm{f}$ \\
\hline $\mathrm{V}_{1} \mathrm{~N}_{3}$ & $2.5 \mathrm{ab}$ & $10.2 \mathrm{~cd}$ & 1.4 & $2.23 \mathrm{a}$ & $15.79 \mathrm{~b}$ & $32.27 \mathrm{ef}$ \\
\hline $\mathrm{V}_{1} \mathrm{~N}_{4}$ & $2.6 \mathrm{a}$ & $10.4 \mathrm{~b}-\mathrm{d}$ & 1.5 & $2.20 \mathrm{ab}$ & $18.04 \mathrm{a}$ & $33.00 \mathrm{de}$ \\
\hline $\mathrm{V}_{2} \mathrm{~N}_{0}$ & $1.0 \mathrm{j}$ & $10.4 \mathrm{~b}-\mathrm{d}$ & 1.6 & $0.84 \mathrm{i}$ & $4.26 \mathrm{k}$ & 21.301 \\
\hline $\mathrm{V}_{2} \mathrm{~N}_{1}$ & $1.3 \mathrm{hi}$ & $10.6 \mathrm{a}-\mathrm{c}$ & 1.7 & $1.53 \mathrm{~g}$ & $9.44 \mathrm{~h}$ & $33.80 \mathrm{~cd}$ \\
\hline $\mathrm{V}_{2} \mathrm{~N}_{2}$ & $1.4 \mathrm{hi}$ & $10.6 \mathrm{a}-\mathrm{c}$ & 1.7 & $1.69 \mathrm{fg}$ & $9.77 \mathrm{~h}$ & $34.43 \mathrm{bc}$ \\
\hline $\mathrm{V}_{2} \mathrm{~N}_{3}$ & $1.3 \mathrm{hi}$ & $11.3 \mathrm{a}$ & 1.8 & $2.12 \mathrm{a}-\mathrm{c}$ & $11.45 \mathrm{~g}$ & $35.00 \mathrm{~b}$ \\
\hline $\mathrm{V}_{2} \mathrm{~N}_{4}$ & $1.8 \mathrm{~g}$ & $11.1 \mathrm{ab}$ & 1.8 & $2.14 \mathrm{a}-\mathrm{c}$ & $13.46 \mathrm{c}-\mathrm{e}$ & $36.10 \mathrm{a}$ \\
\hline $\mathrm{V}_{3} \mathrm{~N}_{0}$ & $1.5 \mathrm{~g}$ & $9.8 \mathrm{c}-\mathrm{e}$ & 1.4 & $1.18 \mathrm{~h}$ & $7.02 \mathrm{i}$ & $19.33 \mathrm{~m}$ \\
\hline $\mathrm{V}_{3} \mathrm{~N}_{1}$ & $2.0 \mathrm{f}$ & $10.5 \mathrm{~b}-\mathrm{d}$ & 1.4 & $1.81 \mathrm{~d}-\mathrm{f}$ & $11.13 \mathrm{~g}$ & $26.73 j$ \\
\hline $\mathrm{V}_{3} \mathrm{~N}_{2}$ & $2.2 \mathrm{c}-\mathrm{e}$ & $10.6 \mathrm{a}-\mathrm{c}$ & 1.4 & $2.05 \mathrm{a}-\mathrm{c}$ & $11.68 \mathrm{fg}$ & $28.13 \mathrm{hi}$ \\
\hline $\mathrm{V}_{3} \mathrm{~N}_{3}$ & $2.2 \mathrm{c}-\mathrm{e}$ & $10.3 \mathrm{~b}-\mathrm{d}$ & 1.4 & $2.01 \mathrm{a}-\mathrm{d}$ & $11.76 \mathrm{fg}$ & $29.17 \mathrm{gh}$ \\
\hline $\mathrm{V}_{3} \mathrm{~N}_{4}$ & $2.3 \mathrm{c}$ & $10.3 \mathrm{~b}-\mathrm{d}$ & 1.4 & $2.05 \mathrm{a}-\mathrm{c}$ & $12.61 \mathrm{ef}$ & $31.53 \mathrm{f}$ \\
\hline $\mathrm{V}_{4} \mathrm{~N}_{0}$ & $1.2 \mathrm{i}$ & $8.8 \mathrm{f}$ & 1.5 & $1.01 \mathrm{hi}$ & $5.73 \mathrm{j}$ & $16.60 n$ \\
\hline $\mathrm{V}_{4} \mathrm{~N}_{1}$ & $2.0 \mathrm{ef}$ & $9.7 \mathrm{de}$ & 1.5 & $1.98 \mathrm{~b}-\mathrm{e}$ & $13.01 \mathrm{de}$ & $25.07 \mathrm{k}$ \\
\hline $\mathrm{V}_{4} \mathrm{~N}_{2}$ & $2.1 \mathrm{~d}-\mathrm{f}$ & $10.4 \mathrm{~b}-\mathrm{d}$ & 1.6 & $2.14 \mathrm{a}-\mathrm{c}$ & $13.59 \mathrm{c}-\mathrm{e}$ & $27.07 \mathrm{ij}$ \\
\hline $\mathrm{V}_{4} \mathrm{~N}_{3}$ & $2.2 \mathrm{~cd}$ & 9.0 ef & 1.5 & $2.15 \mathrm{a}-\mathrm{c}$ & $13.69 \mathrm{~cd}$ & $28.50 \mathrm{~h}$ \\
\hline $\mathrm{V}_{4} \mathrm{~N}_{4}$ & $2.3 \mathrm{bc}$ & $10.2 \mathrm{~cd}$ & 1.5 & $2.13 \mathrm{a}-\mathrm{c}$ & $14.43 \mathrm{c}$ & $29.83 \mathrm{~g}$ \\
\hline Significance & $* *$ & $*$ & ns & $* *$ & $* *$ & $* *$ \\
\hline $\mathrm{CV} \%$ & 5.5 & 4.4 & 6.2 & 6.59 & 4.98 & 2.29 \\
\hline
\end{tabular}

Note: $\mathrm{DAE}=$ Days after emergence, $\mathrm{CV}=$ Coefficient of variation, $\mathrm{ns}=$ not significant, ${ }^{*}$ Significant at $5 \%$ level, **Significant at $1 \%$ level. Figures in a column followed by same or no latter do not differ significantly at $5 \%$ level. $\mathrm{V}_{1}=$ Hybrid baby corn-271, $\mathrm{V}_{2}=$ Shuvra, $\mathrm{V}_{3}=$ Khoibhutta, $\mathrm{V}_{4}=$ BARI sweet corn- $1, \mathrm{~N}_{0}=0 \mathrm{kgN} \mathrm{ha}{ }^{-1}, \mathrm{~N}_{1}=$ $80 \mathrm{kgN} \mathrm{ha}^{-1}, \mathrm{~N}_{2}=120 \mathrm{kgN} \mathrm{ha}^{-1}, \mathrm{~N}_{3}=160 \mathrm{kgN} \mathrm{ha}^{-1}, \mathrm{~N}_{4}=200 \mathrm{kgN} \mathrm{ha}^{-1}$.

\subsection{Plant Population and Period of Harvest of Baby Corn}

\subsubsection{Effects of Variety on the Plant Population and Period of Harvest of Baby Corn}

Variation in plant population $\mathrm{m}^{-2}$ at harvest was statistically non-significant among the varieties but significant in case of $\mathrm{N}$ fertilizer rates (Table 1). The harvesting period of all varieties was statistically significant (Table 1). The maximum period of harvest (9.3) was recorded in Khoibhutta while the minimum harvesting period (5.3) was recorded in Hybrid Baby Corn-271 and it was statistically similar (5.6) to Shuvra. 


\subsubsection{Effect of N-Level on the Plant Population and Period of Harvest of Baby Corn}

Maximum plant population $\mathrm{m}^{-2}(7.0)$ at harvest was found in $200 \mathrm{~kg} \mathrm{~N} \mathrm{ha}^{-1}$ and the minimum plant stand (6.5) was recorded in $0 \mathrm{~kg} \mathrm{~N} \mathrm{ha}^{-1}$ (Table 1). Harvesting period was not statistically significant for $\mathrm{N}$ fertilizer rates and it ranged from 7-8 days.

\subsubsection{Interaction of Variety and N-Level on the Plant Population and Period of Harvest of Baby Corn}

The interaction effect of plant population at harvest was not statistically significant (Table 2). There were no consistency for different combinations of varieties and $\mathrm{N}$-rates. Maximum plant population $\mathrm{m}^{-2}$ at harvest (7.2) was found in BARI sweet corn-1 at $200 \mathrm{~kg} \mathrm{~N} \mathrm{ha}^{-1}$ which was similar to Hybrid baby corn-271 and Shuvra at 160 $\mathrm{kg} \mathrm{N} \mathrm{ha}^{-1}$. Khoibhutta had the lowest (6.1) plant population $\mathrm{m}^{-2}$ at harvest with $0 \mathrm{~kg} \mathrm{~N} \mathrm{ha}^{-1}$. Interaction effect of variety and $\mathrm{N}$ fertilizer was found significant for period of harvest. The maximum harvesting period (10.3) was recorded in BARI sweet corn-1 at $0 \mathrm{~kg} \mathrm{~N} \mathrm{ha}^{-1}$ followed by Khoibhutta (10.3) at $200 \mathrm{~kg} \mathrm{~N} \mathrm{ha}^{-1}$. The minimum harvesting period (5.0) was recorded in Hybrid Baby Corn-271 with $0 \mathrm{~kg} \mathrm{~N} \mathrm{ha}^{-1}$. The results revealed that generally, harvesting period was higher in Hybrid baby corn-271 and Shuvra but lower in Khoibhutta and BARI sweet corn-1 varieties at all rates of $\mathrm{N}$ fertilizer.

\section{Discussion}

Interaction effects of variety and $\mathrm{N}$ fertilizer was significant for plant height of different baby corn varieties at all growing stages. The tallest plant was obtained from Shuvra at $200 \mathrm{~kg} \mathrm{~N} \mathrm{ha}^{-1}$ and the shortest from BARI Sweet Corn-1 at $0 \mathrm{~kg} \mathrm{~N} \mathrm{ha}^{-1}$ at all growth stages. Plant height was significantly different among the varieties at all growth stages and it increased sharply onward 35 DAE indicating proper amount of nutrients and water supply need to be ensured in the crop field at this time. Finally, Shuvra produced the tallest plant $(179.1 \mathrm{~cm})$ and BARI Sweet Corn-1 produced the shortest plant $(149.3 \mathrm{~cm})$. The variation observed among the varieties was mainly due to variation of varietal characters. The result was corroborated with Kgasago (2006) who reported significant variation among the varieties of baby corn in terms of plant height. Plant height differed significantly at all growth stages for $\mathrm{N}$-levels. Usually $\mathrm{N}$-fertilizer enhances the growth of a crop plant synthesizing more protein and chlorophyll. This helps to increase the plant height and other growth parameters. Thakur and Sharma (1999) reported that plant height of baby corn was found significantly increased up to $200 \mathrm{~kg} \mathrm{~N} \mathrm{ha}^{-1}$. Plant height increased significantly with the increase of N-levels was observed by the other scientists also (Thakur, Prakash, \& Kharwara, 1997; Sahoo \& Panda, 1999; Sunder Singh, 2001).

Interaction between variety and $\mathrm{N}$ fertilizer was found significant for days to first tasseling and days to silking. Comparatively both the varieties Hybrid baby corn-271 and Shuvra took about 15 days more for days to tasseling and days to silking than the varieties Khoibhutta and BARI Sweet Corn-1 with all levels of N fertilizers. The results indicated that Khoibhutta and BARI Sweet Corn-1 were the early varieties while Hybrid Baby Corn-271 and Shuvra were the late varieties. The results also indicated that initiation of reproductive stages was not influenced by the application of $\mathrm{N}$ fertilizer.

Interaction of variety and different $\mathrm{N}$ fertilizer doses exerted significant variation on DM accumulation and CGR values at all growth periods. Since the variety Shuvra had the tallest plant, in most cases it produced the highest $\mathrm{DM}$ and CGR values with the application of $160 \mathrm{~kg}$ and $200 \mathrm{~kg} \mathrm{~N} \mathrm{ha}^{-1}$. It was observed that $0 \mathrm{~kg} \mathrm{~N} \mathrm{ha}^{-1}$ produced the lowest DM at all growth stages but not in conjunction with same variety while $0 \mathrm{~kg} \mathrm{~N} \mathrm{ha}^{-1}$ had the lowest CGR values at all periods in conjunction with same variety of Khoibhutta. These findings expressed that growth parameters studied in the experiment increased not significantly beyond $160 \mathrm{~kg} \mathrm{~N} \mathrm{ha}^{-1}$. Dry matter accumulation was lower in low rates of $\mathrm{N}$ and it was minimum in $0 \mathrm{~kg} \mathrm{~N} \mathrm{ha}^{-1}$ at all growth stages but the differences of DM accumulation at advanced stages were higher than early stages. This indicated that more $\mathrm{N}$ required with the progress of plant growth but when $\mathrm{N}$ became a limiting factor at later stages it affected adversely on DM accumulation. Lee-Joung, Park, Chung, and Kim (2005) reported similar results. Sunder Singh (2001) reported that in baby corn, increasing nitrogen levels recorded significant increase in dry matter production in maize up to $150 \mathrm{~kg} \mathrm{ha}^{-1}$ but it was comparable with $180 \mathrm{~kg} \mathrm{ha}^{-1}$ both in kharif and summer seasons. CGR was influenced significantly by different levels of $\mathrm{N}$-fertilizer at all growth periods. Haque, Hamid, and Bhuiyan (2001) reported that nitrogen is a component of protein and nucleic acids and lower nitrogen reduces the crop growth. Rasheed, Ali, and Mahmood (2004) and Alwony and Hasson (1997) reported similar results. Mian, Ahmed, and Matin (2002) reported that CGR value increased with the increase of nitrogen fertilizer. CGR values were increased with the progress of the growth and development of the crop. The findings are in agreement with Khaleque (2005). Hossain and Shahjahan (2008) opined that CGR value was slow at early growth because of incomplete cover and low percentage of sunlight interception which corroborated with the present study. LAI was found highly significant at all growth periods. Shuvra gave significantly highest LAI with $200 \mathrm{~kg} \mathrm{~N} \mathrm{ha}^{-1}$ at all growth 
stages except 65 DAE. At 65 DAE, the highest LAI was recorded in Shuvra with $160 \mathrm{~kg} \mathrm{~N} \mathrm{ha}^{-1}$. It was observed that all varieties showed the lowest LAI with $0 \mathrm{~kg} \mathrm{~N} \mathrm{ha}^{-1}$. Sorensen, Stone, \& Rogers (2000) stated that synchrony between maximum LAI and solar radiation had a great influence on yield of maize. The results revealed that short duration variety like Khoibhutta and BARI Sweet Corn-1 had less LAI than the long duration variety might be due to small plant stature along with decreased number of leaf and size. Modarres, Hamilton, Dwyer, Dijak, and Smith (1998) reported similar results. LAI is important in determining radiation interception up to a value of about 4.0 in maize, after that additional leaf area has little effect on light interception (Tollenaar, Aguilera, \& Nissanka, 1997). Bindhani et al. (2007) stated that in baby corn, application of $120 \mathrm{~kg} \mathrm{~N} \mathrm{ha}{ }^{-1}$ resulted in tallest plant with maximum dry matter yield and leaf area index, which were significantly higher than those at remaining lower levels of nitrogen. Thakur et al. (1997) studied the response of baby corn to different levels of nitrogen and found that growth parameters viz., plant height, leaf area and dry matter accumulation were increased with increasing levels of nitrogen application up to $150 \mathrm{~kg} \mathrm{~N} \mathrm{ha}^{-1}$.

Interaction effects of baby corn varieties and $\mathrm{N}$ fertilizer rate were statistically significant in case of ear plant ${ }^{-1}$, ear length, ear yield without husk, ear yield with husk and fodder yield. Thakur et al. (1997) noticed increased number of baby corn cobs plant ${ }^{-1}$ with $200 \mathrm{~kg} \mathrm{~N} \mathrm{ha}^{-1}$ compared to no nitrogen. Length of baby corn, weight of ear and number of ears plant ${ }^{-1}$ were found to be the highest with $120 \mathrm{~kg} \mathrm{~N} \mathrm{ha}^{-1}$ (Sahoo \& Panda, 1999). Bindhani et al. (2007) observed that in baby corn a significant increase in baby corns plant ${ }^{-1}$, their fresh weight, length and girth were also recorded up to $120 \mathrm{~kg} \mathrm{~N} \mathrm{ha}^{-1}$. Lee-Joung et al. (2005) opined that ear length increased with the increase of N-levels. Thakur and Sharma (1999) registered higher number of baby corn plant ${ }^{-1}$ and length of baby corn with $200 \mathrm{~kg} \mathrm{~N} \mathrm{ha}^{-1}$ as compared to $100 \mathrm{~kg} \mathrm{~N} \mathrm{ha}^{-1}$. Contrary to this, significant differences were not observed in the weight of cob when nitrogen was applied at 100,150 and $200 \mathrm{~kg} \mathrm{ha}^{-1}$ to baby corn (Thakur \& Sharma, 1999). Similar result was obtained in this study being baby corn yield without husk did not differ significantly at 120,160 and $200 \mathrm{~kg} \mathrm{~N} \mathrm{ha}^{-1}$ in Khoibhutta and BARI sweet corn-1. Baby corn yield without husk also did not differ significantly in Hybrid baby corn-271 and Shuvra with 160 and $200 \mathrm{~kg} \mathrm{~N} \mathrm{ha}^{-1}$. Higher baby corn yield without husk was ascribed to higher of ear plant ${ }^{-1}$ and ear length mainly. Pandey, Ved, Mani, \& Singh (2000.) reported that the number of baby corn cobs plant ${ }^{-1}$ and cob weight were highest with $120 \mathrm{~kg} \mathrm{~N} \mathrm{ha}^{-1}$ than at 60 and $90 \mathrm{~kg} \mathrm{~N} \mathrm{ha}^{-1}$ but did not observe any significant difference in the length of baby corn with increased levels of nitrogen from 60 to $120 \mathrm{~kg} \mathrm{~N} \mathrm{ha}^{-1}$. The increased availability of photosynthates might have enhanced number of flowers and their fertilization resulting in higher number of yield attributes. Further, in most of cereals, greater assimilating surface at reproductive developments results in better green cob formation because of adequate production of metabolites and their translocation towards cob. The results of present experiment indicating positive response of various yield attributes to higher nitrogen fertilization accordance findings of several researchers (Chillar \& Kumar, 2006; Bindhani et al., 2007; Gosavi \& Bhagat, 2009; Prodhan, Bala, \& Khoyumthem, 2007) opined that the higher green cob yield produced with application of higher nitrogen could be ascribed to its profound influence on vegetative and reproductive growth of the crop. The results of the present investigation are in accordance with findings of Raja (2001), Thakur and Sharma (1999) and Kumar (2009). Thakur et al. (1997) studied the response of baby corn to different levels of nitrogen and found that nitrogen fertilization had noticeable influence on crop growth and yield of baby corn. Application of $120 \mathrm{~kg} \mathrm{~N}$ $\mathrm{ha}^{-1}$ resulted in the maximum weight of baby corn without husk compared to other levels of $\mathrm{N}$ viz., $0,20,40,60$, 80 and $100 \mathrm{~kg} \mathrm{~N} \mathrm{ha}^{-1}$ (Sahoo \& Panda, 1997). These results corroborate the findings of Sunder Singh (2001) who observed comparable yields at 150 and $180 \mathrm{~kg} \mathrm{~N} \mathrm{ha}^{-1}$. Thakur et al. (1997) demonstrated that baby corn weight with and without husk was found increased significantly with successive increase in N levels up to $100 \mathrm{~kg} \mathrm{~N} \mathrm{ha}^{-1}$. Singh, Singh, Singh, Yadav, and Singh (2010) reported that significant increase in baby corn weight, cobs plant ${ }^{-1}$, baby corn girth was observed with the application of $180+38.7+74.7 \mathrm{~kg} \mathrm{~N}+\mathrm{P}+\mathrm{K}$ ha $^{-1}$ compared to $60+12.9+$ $24.9 \mathrm{~kg} \mathrm{~N}+\mathrm{P}+\mathrm{K} \mathrm{ha}^{-1}$. Yield attributes increased with increased rates of $\mathrm{N}$ might be due to the fact that application of nitrogen to the maize plants maintained greenness of leaves for longer period which in turn helped in greater dry matter accumulation and this might have contributed much as a major source for the development of sink and thereby improved the yield attributes. Significantly highest fodder yield was recorded in Shuvra with $200 \mathrm{~kg} \mathrm{~N} \mathrm{ha}^{-1}$ and the lowest was recorded in Khoibhutta with $0 \mathrm{~kg} \mathrm{~N} \mathrm{ha}^{-1}$ indicating a faster growth under influence of higher level of nitrogen fertilization might have played a significant role in reducing competition for photosynthates and nutrients with other plants resulting in healthy plants.

\section{Conclusion}

The results revealed that both the long duration varieties Hybrid Baby Corn-271 and Shuvra produced comparable baby corn yield without husk at 160 and $200 \mathrm{~kg} \mathrm{~N} \mathrm{ha}^{-1}$. On the contrary, other two short duration varieties Khoibhutta and BARI Sweet Corn-1 produced comparable baby corn yield without husk at 120, 160 and $200 \mathrm{~kg}$ 
$\mathrm{ha}^{-1}$. Hence it may be suggested that to attain the maximum yield without husk and for cultivation of the following crop earlier Khoibhutta and BARI Sweet Corn-1 varieties may be grown with $120 \mathrm{~kg} \mathrm{~N}^{-1}$ in the similar areas having climatic and edaphic conditions of this experiment.

\section{References}

Ahmed, F. (1994). Maize Production Technology (in Bengali). International Fertilizer Development Center (IFDC)-Consultant of Ministry of Agriculture, Bangladesh.

Alwony, M. F., \& Hasson, S. A. (1997). Effect of different levels of dried blood and nitrogen on growth and yield of corn (Zea mays). International Wheat and Maize Improvement Centre, Mexico.

BARI-Bangladesh Agricultural Research Institute. (2008). BARI Annual Research Report 2007-08. Effect of season and population density on growth, fodder production and yield of baby corn at different locations. Agronomy Division, BARI, RARS, Hathazari, Chittagong, Bangladesh.

BARI-Bangladesh Agricultural Research Institute. (2004). Production Technology of Baby Corn (in Bengali). Agronomy Division, BARI, Joydebpur, Gazipur, Bangladesh.

Bar-Zur, A., \& Saadi, H. (1990). Prolific maize hybrids for baby corn. Journal of Horticultural Science, 65, 97-100.

Bindhani, A., Barik, K. C., Garnayak, L. M., \& Mahapatra, P. K. (2007). Nitrogen management in Baby corn (Zea mays). Indian Journal of Agronomy, 52, 135-138.

Chillar, R. K., \& Kumar, A. (2006). Growth and yield behaviour of sweet corn (Zea mays L. saccharata) under varying plant population and nitrogen level. In Extended Summaries of Golden Jubilee National Symposium on conservation Agriculture and Environment (pp. 277-278). Held during 26-28 October, 2006, Banaras Hindu University, Varanasi, India.

Das, S., Yadav, V. K., Jat, M. L., Asha, K., Sujay, R., Jyoti, K., ... Sekhar, J. C. (2008). Baby corn in India. DMR Technical Bulletin 2008 (pp. 1-45). Directorate of Maize Research, Pusa campus, New Delhi.

Gosavi, S. P., \& Bhagat, S. B. (2009). Effect of nitrogen levels and spacing on yield attributes, yield and quality parameters of baby corn (Zea mays). Annals Agricultural Research, 30, 125-128.

Haque, M. M., Hamid, A., \& Bhuiyan, N. I. (2001). Nutrient uptake and productivity as affected by nitrogen and potassium application levels in maize sweet potato intercropping system. Korean Journal of Crop Science, $46,1-5$.

Hossain, A., \& Shahjahan, M. (2008). Grain quality evaluation of the major varieties or cultivar of maize. Research Report for 2006-07 (pp. 1-6). Post Harvest and Technology Division, Bangladesh Agricultural Research Institute, Gazipur.

Kgasago, H. (2006). Effect of planting dates and densities on yield and yield components of short and ultra-short growth period of maize (Zea mays L.) (pp. 55-92). PhD Dissertation, University of Pretoria, South Africa.

Khaleque, M. A. (2005). Study on growth and yield of modern wheat varieties in different management practices (pp. 65-84). PhD Thesis. Institute of Biological Sciences, University of Rajshahi, Bangladesh.

Kumar, A. (2009). Production potential and nitrogen-use efficiency of sweet corn (Zea mays) as influenced by different planting densities and nitrogen levels. Indian Journal of Agricultural Science, 79, 351-355.

Lee-Joung, K., Park, I. I., Chung, J., \& Kim, J. (2005). Effect of planting densities and nitrogen levels on the growth characteristics, dry matter yield and nutritive value of corn for silage in alpine areas. Journal of the Korean Society of Grassland Science, 25, 239-244. http://dx.doi.org/10.5333/KGFS.2005.25.4.239

Mian, M. A. K., Ahmed, A., \& Matin, A. (2002). Growth, yield and economics of hybrid maize as affected by rate and time of nitrogen application. Bangladesh Journal of Agricultural Research, 27, 41-46.

Modarres, A. M., Hamilton, R. I., Dwyer, L. M., Dijak, M., \& Smith, D. L. (1998). Leafy reduce-stature maize for short season environments: Population density and planting pattern effect on hybrid performance. Maydica, 43, 227-234.

Pandey, A. K., Mani, V. P., Prakash, V., Singh, R. D., \& Gupta, H. S. (2002). Effect of varieties and plant densities on yield, yield attributes and economics of baby corn (Zea mays). Indian Journal of Agronomy, 47, 221-226.

Pandey, A. K., Ved, P., Mani, V. P., \& Singh, R. D. (2000). Effect of rate of nitrogen and time of application on yield and economics of baby corn (Zea mays L.). Indian Journal of Agronomy, 45, 338-343. 
Prodhan, H. S., Bala, S., \& Khoyumthem, P. (2007). Response to rate of nitrogen and effect of plant density on yield of baby corn. Journal of Interacademicia, 11, 265-269.

Raja, V. (2001). Effect of nitrogen and plant population on yield and quality of super sweet corn (Zea mays). Indian Journal of Agronomy, 46, 246-249.

Ramachandrappa, B. K., Nanjappa, I. I. V., \& Shivakumar, I. I. K. (2004). Yield and quality of baby corn (Zea mays L.) as influenced by spacing and fertilization levels. Acta Agronomica Hungarica, 52, $237-243$. http://dx.doi.org/10.1556/AAgr.52.2004.3.4

Rasheed, M., Ali, H., \& Mahmood, T. (2004). Impact of nitrogen and sulfur application on growth and yield of maize crop. Pakistan Journal of Research (Science), 15, 153-157.

Sahoo, S. C., \& Panda, M. M. (1997). Fertilizer requirement of baby corn (Zea mays) in wet and winter seasons. Indian Journal of Agricultural Science, 67, 397-398.

Sahoo, S. C., \& Panda, M. M. (1999). Effect of level of nitrogen and plant population on yield of baby corn (Zea mays). Indian Journal of Agricultural Science, 69, 157-158.

Salahuddin, M., \& Ivy, N. A. (2003). Cultivation of Maize. Production and Uses of Maize in Bangladesh (In Bengali) (pp. 29-35).

Singh, M. K., Singh, R. N., Singh, S. P., Yadav, M. K., \& Singh, V. K. (2010). Integrated nutrient management for higher yield, quality and profitability of baby corn (Zea mays). Indian Journal of Agronomy, 55, 100-104.

Sorensen, I., Stone, P., \& Rogers, B. (2000). Effect of sowing time on yield of a short and a long season maize hybrid. Agronomy Journal of New Zealand, 30, 63-66.

Sundar Singh, S. D. (2001). Effect of irrigation regimes and nitrogen levels on growth, yield and quality of baby corn. Madras Agricultural Journal, 88, 367-370.

Thakur, D. R., \& Sharma, V. (1999). Effect of varying rates of nitrogen and its schedule of split application in baby corn (Zea mays). Indian Journal of Agricultural Science, 69, 93-95.

Thakur, D. R., Prakash, O. M., Kharwara, P. C., \& Bhalla, S. K. (1997). Effect of nitrogen and plant spacing on growth, yield and economics of baby corn (Zea mays). Indian Journal of Agronomy, 42(3), 479-483.

Tollenaar, M., Aguilera, A., \& Nissanka, S. P. (1997). Grain yield is reduced more by weed interference in an old than in a new maize hybrid. Agronomy Journal, 89, 239-246. http://dx.doi.org/10.2134/agronj1997.00021962008900020014x

UNDP \& FAO. (1988). Land Resources Appraisal of Bangladesh for Agricultural Development. Report No. 2. Agro-Ecological Regions of Bangladesh (pp. 212-221). United Nations Development Program and Food and Agriculture Organization. Bangladesh Agricultural Research Council, Farmgate, Dhaka.

Vafias, B. N., \& Ipsilandis, C. G. (2005). Combining ability, gene action and yielding performance in maize. Asian Journal of Plant Science, 4, 50-55. http://dx.doi.org/10.3923/ajps.2005.50.55

Venekamps, J. H., Vries, F. W. T. P. de, \& Koot, J. T. M. (1985). Influence of different levels of nitrogen on nitrogen nutrition and metabolism of maize plants, Zea mays L. Netherlands: Agrobiological Research (pp. 217-226).

Yellamanda Reddy, T., \& Sankara Reddi, G. H. (2005). Growth and Development of Crops (p. 104). Principles of Agronomy. New Delhi: Kalyani publishers.

\section{Copyrights}

Copyright for this article is retained by the author(s), with first publication rights granted to the journal.

This is an open-access article distributed under the terms and conditions of the Creative Commons Attribution license (http://creativecommons.org/licenses/by/3.0/). 